\title{
Privatization and Financial Performance in Developing Countries: Reality and Myth
}

\author{
Abdulla A. R. Ali ${ }^{1}$ \\ ${ }^{1}$ College of Business Administration, Department of Accounting, University of Bahrain, Bahrain \\ Correspondence: Abdulla A. R. Ali, College of Business Administration, Department of Accounting, University \\ of Bahrain, Bahrain. E-mail: mohanad52@hotmail.com
}

Received: Novemeber 11, 2013

Accepted: January 14, 2014

Online Published: March 21, 2014

doi:10.5539/ijbm.v9n4p115

URL: http://dx.doi.org/10.5539/ijbm.v9n4p115

\begin{abstract}
During the 1980s, the pendulum swung back from the socialism doctrinaire that dominated the post war period, where public ownership of the productive and services sectors was emphasized. In the early 1980s, new values emerged questioning the role of the state in economic activities. As a result, the pressures mounted to shift to market economy and to rely on private initiatives to spearhead the development process.

Accordingly, governments around the globe, including communist countries, announced their intentions to "rolling back the frontiers of the state". The unsatisfactory performance of public enterprises, it was argued, is a direct consequence of their ownership structure. Therefore, the only enduring remedy that emerged was to change ownership.

In this paper we assess the efficiency arguments for and against privatization with emphasis on developing countries. It is here argued that the poor performance of public enterprises is due to market structure and lack of clear objectives rather than structure of ownership. Moreover, although there is evidence that privatized firms have improved, we assert that the claimed improvement is difficult to measure, due to the major restructuring that were carried out before privatization to prepare the candidates in order to ensure success of the policy and the change of environment within which they operate. These methodological problems make such comparison before and after at least a protracted and complicated business and the results highly debatable.
\end{abstract}

Keywords: privatization, efficiency, public enterprises (PEs), developing countries (DCs)

\section{Introduction}

During the 1980s, the pendulum swung back from the socialism doctrinaire that dominated the post war period, where public ownership of the productive and services sectors was emphasized. In the early 1980s, due to poor performance, new values emerged questioning the role of the state in economic activities. As a result, the pressures mounted to shift to market economy and to rely on private initiatives to spearhead the development process.

In effect, governments around the globe, including communist countries, announced their intentions to "rolling back the frontiers of the state". The unsatisfactory performance of public enterprises, it was argued, is a direct consequence of their ownership structure. Therefore, the only enduring remedy that emerged was to change ownership from public to private (privatization).

\section{Literature Review}

Between the late 1940s and 1970s, a universal consensus existed regarding the role of the state in economic activities. Both socialist and capitalist governments, in both developed and developing countries, engaged in creating a wide range of enterprises to provide goods and services at reasonable prices. The prevailing ideology in most developing countries (here after DCs) was that, political independence must be supported by economic independence, which meant full state ownership of the productive capacity, and expulsion of foreign firms. It was believed that, due to the widespread market failures, central planning was more efficient in allocating resources than the market forces. Thus, governments around the globe established a considerable number of public enterprises (hereafter PEs) in the post war period, on the assumption that public ownership not only contributes to rapid economic growth, but also to socio-political stability. According to public corporation theory, as developed in the UK, this required the creation of enterprises that were accountable to the government, while 
their operating decisions were to be left to their management.

Ideology apart, state ownership was further supported by the Keynesian demand management theory, which stressed the role of public spending in stimulating economic growth, creating jobs, and raising the standards of living. The theory seems to have worked satisfactorily in the post-war period, as inflation remained under control and so did unemployment. Therefore, during this period (late 1940s and 1970s), the role of the state in economic activities was hardly ever challenged.

By the late 1970s, however, that universal consensus began to disappear, as both inflation and employment soared. Consequently, governments around the globe started to reassess their economic role. PEs, it was claimed, were inefficient way of doing business, simply because they had no incentives to control costs, or to provide quality goods demanded by consumers. Moreover, with their unlimited access to public funds, PEs could not go out of business. PE managers, the argument goes, had no incentives to be efficient, to respond to market forces, or to discipline trade unions.

To these economic arguments, an ideological shift took place during the late 1970s adding another contributory factor against PEs, which is largely attributed to the election of governments in industrial countries (e.g., the UK and USA), committed to"rolling back the frontiers of the state." Their arguments were based on an implicit assumption of the superiority of private firms, and a strong belief in the efficiency of free markets. Moreover, state ownership undermined consumer choice, resulted in higher prices, lower productivity, high taxation to finance public spending, reduced incentives to invest, and maximize profits. Therefore, it was argued that, the role of the state should be restricted to ensuring that the right conditions for doing business prevailed.

In effect, the growing dissatisfaction with the performance of PEs have led countries around the globe (socialist and capitalist) to reassess the role of the state in the economy. And developing countries are not an exception.

\section{Research Objective}

The primary objective of this paper to critically investigate the theoretical claims that transfer of ownership from public to private ownership (privatization) would improve financial performance of a business entity.

\subsection{Research Methodology}

The research method used for this paper is a descriptive method of research. The sources of data are primarily secondary data, including: documentary research materials, journals, textbooks, library archival materials and internet sources. The data used in the study were obtained from annual reports published on websites and prospectuses of the privatized firms.

In order to generate comparable post-issue financial and accounting data, our analysis is limited to privatization through direct sale of PEs (public offering or private sale). Not least because but sale has been widely used in practice than other methods of privatization, such as contracting out, employee buyout or deregulation. The purpose of the analysis in this study is to investigate the financial performance of privatized firms using ratio analyses, such as asset turnover, return on capital employed (ROCE), return on shareholders' equity (ROE), gross profit margin (GPM), or growth of turnover.

\subsection{Performance Debate}

To start with, it must be emphasized that, performance measurement is an extremely difficult and a complicated issue. In fact, even for private firms, the available methods of profitability, return on investment and residual income have been heavily criticized in the accounting literature. As for profitability, the hyper inflation experienced by all countries in the late 1970s onwards, made its calculation a protracted and complicated business. Thus, it is by no means clear which profit figure should be used as a performance indicator-that is profits based on historical costs, or those based on current replacement costs. As for most DCs, however, inflation accounting is simply unknown. Secondly, the absence of standardized accounting systems in most DCs creates wide variations in the treatment of depreciation charges, inventory valuation and cost of capital, which affect comparability and consistency. Thirdly, absolute profit figures are entirely meaningless indicators, since they are not related to the investment base used to generate the profits.

Return on Investment, on the other hand, could lead to dysfunctional decisions. For example, in a bid to maximize the rate, management could simply cut costs on training, research and development, reduce the investment base by disposing of marginally-producing assets, or lease rather than buy, all of which would affect the long term value of the firm.

Finally, the residual income method charges the cost of capital as an expense, which makes a firm with a high debt ratio less profitable than that with a high equity ratio. 
As for PEs, however, the issue of performance measurement is further complicated by a number of factors.

First, performance measurement essentially requires a regular flow of reliable, timely information. However, in many DCs, accounting systems are rudimentary, qualified accountants are in severe shortages, and the available financial statements are not prepared according to sound accounting practices (Shirley, 1983).

Second, performance measurement essentially requires comparing standards or targets with the actual results achieved. However, PEs were normally assigned multiple and often conflicting goals, simply because they were created primarily to accelerate socio-economic development, and hence profitability was not a main objective. For example, to promote rural development, PEs were often located in remote rural areas that lack the basic infrastructure or the raw material supply; to curb inflation their prices were often set at unrealistic levels; and to contain unemployment they were normally overstaffed. As a result, their poor performance could be attributed to the presence of these social and macroeconomic objectives.

Third, PE managers were often selected on the basis of political acceptance rather than knowledge and experience in business management. PE managers have no autonomy over prices or personnel policies, no incentives or punishments if performance improved or deteriorated, and they are often constrained by tight bureaucratic controls that limit their operational autonomy.

On the other hand, PEs have unlimited access to public funds, and exempted from custom duties. They might be required to acquire their inputs from other PEs at a price far below (or above) the prevailing market prices and the suppliers may never be paid. Moreover, both public and private enterprises in most DCs are often protected from imports, which makes the local market more profitable than the international market. Therefore, good performance could be attributed to the market structure, rather than internal efficiency.

For all these reasons, therefore, financial performance as reflected in the income statement might be a poor and misleading indicator of financial performance.

In what follows, we assess the proposed alternative policy to remedy public ownership problems, in terms of definition, objectives, merits and demerits.

Privatization: Definition and Objectives

Unfortunately, there is no specific precise definition of the term. Privatization is a word unknown before 1980, is "an ugly word" (Heald, 1985), a concept that evokes sharp political reaction and "should be heavily escorted by inverted commas as a reminder that its meaning is uncertain and often tendentious" (Donnison, 1984). In fact, it does not even appear in the Oxford dictionary. It's a word used to describe various policies designed to reduce the role of the state in economic activities and strengthen the role of the market forces. Its about privatization (transfer of ownership and control from the public to private owners) and deregulation.

As for DCs, however, the current interest in privatization is attributed to two main factors: the poor performance of PEs and the external pressures to implement fundamental economic reforms. As foreign loans slowed down due to the recent debt crisis and internal resources dwindled, the deficits generated by PEs became no longer sustained. Therefore, it was argued that the state has to cut back in areas where its presence is not essential. Here we focus on financial performance as a driving force for privatization.

It must be stressed at the outset that, no explicit objectives for the policy were ever clearly stated, nor had the privatization techniques been thought out. Indeed, even in the UK, where major privatizations were carried out, the privatization motives have evolved through time. As Kay and Thompson (1986) argue, "The reality behind the multiplicity of objectives is not that the policy has a sophisticated rationale, but rather that it is lacking any clear analyses of purpose ... any objective which seems achievable is seized as justification." Moreover, there was no specific and clear privatization plan even in developed countries. As Shirley (1989) argued, "For the most part, countries have chosen privatization candidates opportunistically. Rather than formulating and implementing a cohesive privatization strategy, they have selected candidates on some other basis". Nevertheless, a number of objectives have been cited, which can be considered as economic hypothesis capable of being tested against empirical evidence. These are:

(1) Privatization would reduce PE's deficits, decrease the crowding-out of private investment, and generate resources to the Treasury,

(2) Privatization would expose enterprises to the market forces and clarify objectives,

(3) Privatization would lead to wider "real" ownership by the public.

(4) Privatization would eliminate political intervention, and resolve the management and control problems of PEs. 
In addition, countries also differ widely on how to implement privatization to the extent that every one is doing it differently.

In what follows, we shall analyze the potential efficiency arguments for and against privatization, with special reference to DCs.

\subsection{The Efficiency Argument}

Although the microeconomic theory never established a firm link between efficiency and the ownership structure, a number of arguments were made suggesting that privatization would generate significant allocative and productive efficiency benefits. Allocative efficiency implies that the correct combination of goods will be produced, while productive efficiency means that the maximum amount of goods will be produced at the least possible costs. Supporters argued that, public ownership inhibits efficiency, due to lack of incentives and shareholders with a direct interest in the operations of a PE. The tax-payers cannot exert real pressures on management to operate efficiently, and finance is often obtained from the Treasury regardless of performance. Therefore, public managers have no incentives to be financially viable, and the absence of market disciplines imply that PEs can never go out of business. Private enterprises, on the other hand, are exposed to the disciplines of market forces, including the market for corporate control. Thus, if the capital market is efficient, a firm that fails to control costs, reduces its profits, and hence becomes a target for takeover or bankruptcy. The threat of bankruptcy or takeover, therefore, would force management to cut waste and innovate so as to survive. As a result, the product market will enhance allocative efficiency, while the capital market enhances productive efficiency.

Further, it was claimed that, management incentives to maximize profits and control costs are seriously hampered by the structure of ownership. PEs are often given numerous and contradicting goals, and supervised by numerous, ill-coordinated government agencies which hinders corporate governance. Privatization, therefore, would clarify objectives, reduce the number of principals, and eliminate the excessive political interference. Equally, a change of ownership would replace the "uninterested" civil servants by "real" shareholders who have a direct financial stake, and hence exert pressures on management to minimize costs, innovate and seek new markets. Finally, the absence of market disciplines encourages trade unions to demand higher wages regardless of performance. For these reasons, it was claimed that, PEs are less efficient than their private counterparts.

\section{Discussion and Analyses}

The above claims regarding superiority of private enterprises over PEs could be refuted on the following grounds:

First, in the vast majority of DCs, the capital markets are highly inefficient. As Heald (1990) argues "Existing capital markets are not only thin and underdeveloped, but also rife with insider trading and other dubious practices". International takeover is unlikely to be effective, simply because the generally distorted macroeconomic environment, and the unstable legal and political systems in most DCs is likely to deter foreign investors. Second, there is no reason to suggest that the market for corporate control would be efficient once privatization was implemented. Not least because the government could still control takeover bids through the "golden share" mechanism. The "golden share" is a special share that can only be held by the state, and gives the state a "veto power" over certain decisions, including takeover, if the national interest is at stake

Third, PEs were originally created to facilitate political intervention in the interest of development. Indeed, (Ghai, 1985). Claiming that "Public enterprises and the way they operate are ultimately the consequences of the relations between the social forces in a society. If you roll back the state in its more visible manifestations, these forces will come back in another form, less accountable and perhaps even more irresponsible" Equally, privatization would deprive the state from maintaining effective control over macro-economic policies, such as employment, wages and rural development, which are still high on the national agenda.

Forth, there is no firm evidence to support the proposition that private firms in DCs are more efficient than their public counterparts. The same factors that contributed to the poor performance of PEs apply equally to private firms. These include the excessive government intervention in internal markets, the distorted business environment, and the protectionist policies adopted in most DCs to protect the so called "infant industries", public and private. As Nellis and Kikeri (1989) argue"...Leaping from this point to the conclusion that the private sector can not do worse is not a serious argument" More importantly, comparing the performance of public and private firms is a technically difficult task, not least because performance comparison involves comparing identical firms in terms of objectives, size, age, technology, management and market structures. However, it is often rare to find such identical firms, which makes the comparison incomplete and misleading. 
Nevertheless, apart from these methodological problems, the relatively small amount of empirical work carried out so far in DCs point out to mixed results. For example, Millward (1988) concluded that "Similar conclusions were reached by Kirkpatrick (1986); Gupta (1982). The satisfactory performance of enterprises (public and private) from all over the world was attributed largely to the fact that they operate in a competitive market. "Domestic and foreign competition, which leave no room for complacency, appears to have been an important factor. An environment where challenges are non-existent can suffocate the initiative of the best managers, public or private (Ayub \& Hegstad, 1986). This suggests that, the efficiency of an enterprise is determined by the quality of its management and the market structure within which it operates, rather than who owns it (Commander \& Killick, 1988; Shirley, 1989).

Thus, it is competition, local or foreign, that enhances efficiency by forcing management to minimize costs, innovate, develop new products, and seek new markets. In the absence of competition (or threat of competition), there is no reason to suggest that any enterprise, public or private, would be efficient, and the balance could go either way. Indeed, such evidence clearly indicates that significant efficiency gains could be achieved by exposing enterprises, public or private, to greater market forces. Therefore, it is essential to remove entry barriers, encourage exports, expose local firms to foreign competition whenever possible, restructure giant corporations into smaller entities so as to foster competition, rather than to transfer ownership.

Advocates claim that privatization is a necessary condition for deregulation, because PEs backed by the state funds would be able to deter entry. However, apart from the fact that private firms with considerable market powers could equally deter entry, experience shows that privatization had actually inhibited deregulation. The reasons are three-fold. First, breaking-up giant enterprises is often time-consuming, lessens investor's interests, and reduces the sales proceeds, because enterprises operating in a fierce competitive market are unlikely to attract investors. Therefore, preoccupation with the success of the policy for political and financial reasons, could lead to competition, domestic and foreign, being sacrificed. Second, experience shows that the management of the privatization candidates often resist the breaking-up of their entities, so as "to enjoy the quiet life of monopoly" (Kay \& Thompson 1986). Therefore, to ensure their commitment and cooperation, which is essential for the success of the policy, competition could be sacrificed. As Bishop and Kay (1989) argue "The political power of senior management arises from the observation that any privatization which does not enjoy their support will be at best a difficult and protracted process". Similarly, Vuylsteke (1988) states that "preparing large PEs for privatization can not be done without the full commitment of top management". Third, to attract buyers, an increasing number of governments around the globe have granted more protection for the privatization candidates. In the UK, Vuylsteke (1988) stressed that "The long term success of the privatization program will stand or fall by the extent to which it maximizes competition. If competition cannot be achieved, an historic opportunity will have been lost". In reality, that "historic opportunity" has been lost, and powerful enterprises, such as the telecom and gas, were privatized intact, raising serious concerns about the effectiveness of the market for corporate control. The point is that, the size of such firms would hinder the efficiency of the capital market, which hinders the efficiency claims.

In effect, concerns to ensure the success of the policy, and to maintain the support of management had led to the relegation of competition to lower levels. As a result, a regulatory system was suggested to protect consumers against monopoly pricing and poor quality services. As Vuylsteke (1988) claimed, "I firmly believe that where competition is impractical, privatization policies have now been developed to such an extent that regulated private ownership of natural monopolies is preferable to nationalization". However, there is no firm evidence to support the view that regulation is more efficient than public ownership. Moreover, regulation raises difficult questions regarding the capacity of DCs to design and operate a regulatory system. Vuylsteke (1988) asserts that "The introduction of an adequate regulatory framework is more effective control tool than ownership". This is debatable, not least because DCs lack the necessary conditions for the creation of an adequate regulatory framework. The fact is that, in most DCs, there are no standardized reporting systems, no active agencies to protect consumers, the media is controlled by the state, and no established respected, and consistently applied legal system. Indeed, even in the UK, there are growing concerns regarding the efficiency of the regulatory agencies, such as British Telecom and British Gas (Yarrow, 1989). Nevertheless, it is evident that there is a conflict between privatization and deregulation, and experience shows that the former has often been preferred at the expense of deregulation. Advocates, on the other hand, claim that the threat of potential competition might be sufficient to enforce greater efficiency as does actual competition, and hence the number of firms in the market is irrelevant. This argument is based on the "contestable market theory" proposed by Baumol et al (1982), suggests that it is possible to create a competitive market behavior regardless of the number of firms, if the incumbent firm is exposed to threat of potential competition. The theory assumes that if entry involves no sunk 
costs-defined as costs that are irrecoverable by leaving the industry-there would be no exit barriers. Therefore, even a monopolist will not be able to earn monopoly profits, because he would be vulnerable to "hit and run" by a transient, who could enter the market, undercut prices/costs, earn a profit and leave costlessly. Thus, the theory suggests that, it is the entry threat and not the number of firms that determines the competitiveness of a market. A good example of a contestable market is road transport where the theory worked remarkably well. However, opponents claim that the assumptions upon which the theory is based are unrealistic and difficult to satisfy. In particular, the assumption of zero sunk costs was criticized as unrealistic and irrelevant to real life industries, such as the import substitutes. Second, the theory assumes that the entrant can establish itself, earn a profit without any response from the existing firms. This implicit assumption of zero time lag was criticized as unrealistic. Third, the incumbent firm might be able to deter entry through aggressive pricing, raising wages or advertising. Finally, although the efficiency argument was cited more than often as a case for privatization, it is not yet clear how the effects of privatization was identified from major rehabilitations introduced prior to privatization and the threat of privatization itself on performance. It is difficult to speculate about what would have happened had the privatized industries remained under public ownership. These methodological problems, make performance evaluation at best difficult (Yarrow, 1989).

Indeed, the relatively small amount of empirical work carried out so far provide evidence of significant improvement in performance, but are not as strong as effects of liberalizing the environment in which firms operate. Bishop and Kay (1989) compared the performance of various privatized industries in the UK with others that remained public. The authors reported that the privatized industries have improved remarkably, but this improvement, the authors claim, has more to do with the nature of industries concerned. The privatized industries that have grown rapidly (BT, Cable and Wireless) were doing well before privatization, while the Associated British Ports performed poorly under both public and private ownership. Bishop and Kay (1989) also found that the greatest gains occurred in PEs that were not selected for privatization (e.g., British coal). In effect, they concluded that "The significant improvement in the performance of the remaining public sector denies any simple views about the relationship between ownership and performance". Similarly, in a recent study of 81 banks from 22 DCs. Boubakri et al. (2005), found that "In the post-privatization period, profitability increases but, depending on the type of owner, efficiency, risk exposure and capitalization may worsen or improve". Also, Omran (2007) investigated the post privatization performance of Egyptian banks between 1996-1999, and found that "some profitability and liquidity ratios for privatized banks decline significantly, and that the relative performance changes of privatized banks were better than those of mixed banks with majority state ownership but worse than those of banks with other ownership forms (private, state-owned, and mixed private ownership)".

\section{Conclusion}

In summary, there is evidence of significant increases in profitability, output, operating efficiency and dividend payments--and significant decreases in leverage ratios of privatized firms in different parts of the world (D'Souza, 1999) .But, there is no conclusive, firm evidence to support the claims that ownership is the sole determinant of performance. Stronger efficiency gains are observed when foreign ownership is high, and for firms that restructure. On the other hand, evidence from Mexico, showed that privatization outcomes were "bad enough to prompt re-nationalization of the banking sector in the wake of the Tequila crisis" (Haber, 2005). In the Czech Republic, and Poland, bank privatization, "were not fully successful" (Bonin, Hasan \& Wachtel, 2005). In Australia (McKenzie, 2011) found that "Privatized institutions are found to perform quite similarly to private peer institutions both before and after privatization". In DCs, government intervention in internal markets is quite excessive, the environment inhospitable and firms (public and private) are protected against imports. Therefore, there is no reason to suggest that a change in ownership in itself would pave the way for economic efficiency.

It is true that PEs are not exposed to the market disciplines confronting their private counterparts. But, this is not a conclusive ground for privatization. Internal reform through exposing PEs to a more demanding, competitive environment could generate significant efficiency gains. As Hemming and Mansoor (1988) argue "Despite the inconclusive nature of the evidence, it is difficult to believe that existing public enterprises are not capable of achieving significant improvements in efficiency".

However, while we do agree that no satisfactory control system has ever been developed, we shall increasingly argue that, privatization is unlikely to provide a perfect remedy in all cases. First, some of the privatized industries are the "commanding heights" of the economy, and hence the central government would need to get involved in their operations to ensure public interest. The regulatory mechanisms created for the public utilities in the UK and elsewhere provide a powerful demonstration of this assertion. Second, for a number of reasons, governments have opted for joint ownership rather than complete privatization and that raises serious concerns 
about corporate governance. In sum, enterprise performance is determined by allowing market forces to work, by restoring enterprise culture, and by removing unnecessary restrictions and controls. In theory, it is possible to create the kinds of incentives that will maximize efficiency regardless of ownership. Future research need to focus on factors that determine performance rather comparing the unlike. Empirical investigation before and after is irrelevant and will not add to our knowledge due to the methodological complexity.

\section{References}

Adams, S., \& Mengistu, B. (2008). Privatization, governance and economic development in developing countries. Journal of Developing Societies, 24(4), 415-438. http://dx.doi.org/10.1177/0169796X0902400401

Ayub, M., \& Hegstad, S. (1986). Public Industrial Enterprises: Determinants of Performance. Industry and Finance Series, 17.

Baumol, W. J., Banzar, R., \& Williq, D. (1982). Contestable Markets and the Theory of Industry Structure. New York: Harcourt Brace Jovanovich.

Berg, E. (1987). Privatization: Developing a Pragmatic Approach. Economic Impact, No. 57.

Bishop, M., \& Kay, J. (1989). Privatization in the UK: Lessons from Experience. World Development, 17(5). http://dx.doi.org/10.1016/0305-750X(89)90065-X

Bonin, J. P., Hasan, I., \& Wachtel, P. (2005). Bank privatization and performance: evidence from transition countries. Journal of Banking and Finance.

Boubakri, N., \& Cosset, J. (1998). The Financial and Operating Performance of Newly Privatized Firms: Evidence from Developing Countries. Journal of Finance, 53, 1081-1110. http://dx.doi.org/10.1111/0022-1082.00044

Boubakri, N., Cosset, J. C., \& Guedhami, O. (2005). Post privatization corporate governance: the role of ownership structure and investor protection. Journal of Financial Economics, 76, 369-399. http://dx.doi.org/10.1016/j.jfineco.2004.05.003

Candy, S. R. (1988). Techniques of Privatization of State Owned Enterprises. World Bank Technical Papers, No. 90.

Clarke, G., Cull, R., \& Shirley, M. (2005). Empirical studies of bank privatization: an overview. Journal of Banking and Finance.

Commander, S., \& Killik, T. (1988). Privatization in Developing Countries: A Survey of Issues. Brighton: Wheatsheaf Books.

Cunha, R. C., \& Cooper, C. L. (2002). Does privatization affect corporate culture and employee wellbeing? Journal of Managerial Psychology, 17, 21-49. http://dx.doi.org/10.1111/0022-1082.00044

D'Souza, J., \& Megginson, W. (1999). Sources of Performance Improvement in Privatized Firms: A Clinical Study of the Global Telecommunications Industry. Working Paper, University of Oklahoma.

D'Souza, J., \& William, L. M. (1999). The Financial and Operating Performance of Privatized Firms During the 1990s. Journal of Finance. http://dx.doi.org/10.1111/0022-1082.00150

Dharwadkar, R., George, G., \& Brandes, P. (2000). Privatization in emerging economies: an agency theory perspective. Academy of Management Review, 25, 650-669.

Donnisan, D. V. (1984). The Progressive Potential of Privatization. In J. Grand (Ed.), Privatization and Welfare State. Allen and Irwin.

Erakovic, L., \& Wilson, M. (2005). Conditions of radical transformation in state-owned enterprises. British Journal of Management, 16, 293-313. http://dx.doi.org/10.1111/j.1467-8551.2005.00467.x

Estrin, S., \& Perotin, V. (1991). Does Ownership Always Matter? International Journal of Industrial Organization, 9, 55-72. http://dx.doi.org/10.1016/0167-7187(91)90005-6

Fahy, J., Hooley, G., Beracs, J., Fonfara, K., \& Gabrijan, V. (2003). Privatization and sustainable advantage in the emerging economies of Central Europe. Management International Review, 43, 407-428.

Galal, A., Jones, L., Tandon, P., \& Vogeslang, I. (1994). Welfare Consequences of Selling Public Enterprises. Washington, DC.: World Bank. http://dx.doi.org/10.1596/0-8213-2976-6

Ghai, Y. (1985). The State and the Market in the Management of Public Enterprises in Africa. Public Enterprises, 
Ljubljana, 5(1).

Gowland, D., \& Aiken, M. (2003). Privatization: a history and survey of changes in organization structures, cultural, and environmental profiles. Australian Journal of Public Administration, 62, 43-56. http://dx.doi.org/10.1111/1467-8500.00313

Gupta, N. (2005). Partial privatization and firm performance. Journal of Finance, 60, 987-1015. http://dx.doi.org/10.1111/j.1540-6261.2005.00753.x

Gupta, N. (2005). Partial privatization and firm performance. Journal of Finance, 60. http://dx.doi.org/10.1111/j.1540-6261.2005.00753.x

Gupta, R. (1982). Productivity Performance of the Public and Private Sectors in India: A Case Study of Fertilizer Industry. Indian economic Review, 17.

Guriev, S., \& Megginson, W. (2007). Privatization: What have we learned? In F. Bouguignon \& B. Pleskovic (Eds.), Beyond Transition. Annual World Bank Conference on Development. Economics Regional 2007. Washington, DC.: The World Bank.

Haber, S. (2005). Mexico's experiments with bank privatization and liberalization. Journal of Banking and Finance.

Heald, D. (1985). Will Privatization of Public Enterprises Solve the Problem of Control. Public Administration, 63(10). http://dx.doi.org/10.1111/j.1467-9299.1985.tb00582.x

Heald, D. (1990). The Relevance of Privatization in Developing Countries. Public Administration and Development, 10. http://dx.doi.org/10.1002/pad.4230100103

Hemming, R., \& Mansoor, A. (1988). Is Privatization the answer? Finance and Development, 25(2).

Hodge, G. (2000). Privatization: An International Review of Performance. Boulder, CO.: West view Press.

Jerome, A. (2002). Public Enterprise Reform in Nigeria: Evidence from the Telecommunications Industry. AERC Research Paper No. 129. African Economic Research Consortium, Nairobi.

Jerome, A. (2005). Privatization and regulation in South Africa: An evaluation. In Edmund, A. (Ed.), Regulating Development Evidence from Africa and Latin America. Northampton, Massachusetts, and Cheltenham, UK: Edward Elgar Publishing Ltd.

Kay, J., \& Thompson, D. (1986). A Policy in Search of Rationale. The Economic Journal, 96.

Kayizzi, M. S. (2002). Privatization in Sub-Saharan Africa: On Factors Affecting Implementation. WIDER Discussion Paper No. 2002/12. World Institute for Development Economics Research, Helsinki.

Kirkpatrick, C. (1986). The UK Privatization Model: Is it Transferable to Developing Countries. In V. Ramandhan (Ed.), Privatization in the UK. Routledge, London.

Kirkpatrick, C. (1986). World Bank Views in State Owned in Enterprises in Developing Countries. Wheatsheaf Books, Brighton.

La Porta, R., \& López-de-Silanes, F. (1999). Benefits of Privatization-Evidence From Mexico. Quarterly Journal of Economics, 114, 1193-1242. http://dx.doi.org/10.1162/003355399556250

Latifulhayat, A. (2008). The independent regulatory body: a new regulatory institution in the privatized telecommunications industry (the case of Indonesia). International Journal of Technology Transfer and Commercialization, 7(1), 15-33. http://dx.doi.org/10.1504/IJTTC.2008.018800

Leibenstein, B. (1978). General X-Efficiency Theory end Economic Development. New York University.

Martin, S., \& Parker, D. (1997). The Impact of Privatization: Ownership and Corporate Performance in the UK. Routledge, London. http://dx.doi.org/10.4324/9780203439012

McKenzie. (2011). Privatization and performance: the case of four Australian financial institutions. Journal of Annals of Public and Cooperative Economics, 82(3).

Megginson, W., Nash, R., \& Randenborgh, M. (1994). The Financial and Operating Performance of Newly Privatized Firms: An International Empirical Analysis. Journal of Finance, 49. http://dx.doi.org/10.1111/j.1540-6261.1994.tb05147.x

Millward, R. (1988). Measured Sources of Inefficiency in the Performance of Public and Private Enterprises in DCs. New York: St Martin's press. 
Nellis, J., \& Kikri, S. (1989). Privatization of Public Enterprises. CECPS, World Bank,

Omran, M. (2007). Privatization, State Ownership, and Bank Performance in Egypt. World Development. http://dx.doi.org/10.1016/j.worlddev.2006.07.002

Parker, D. (2000). Introduction: privatization and corporate performance. In D. Parker (Ed.), Privatization and Corporate Performance. Edward Elgar, Cheltenham.

Shirley, M. (1989). Bank Lending of State Owned Enterprises Reform: A Review of and Lessons of Experience. CECPS, World Bank.

Vuylsteke, C. (1988). Techniques of Privatization of State Owned Enterprises.

Williamson, O. (1963). Managerial Discretion and Business Behavior. American Economic Review.

World Bank. (1999). Recent trends in private participation in infrastructure. Public Policy for the Private Sector Viewpoint No. 196. Washington, DC.: World Bank,

World Bank. (2007). Privatization Trends. Washington, DC.: World Bank.

Yarrow, G. (1989). Does Ownership Matter? In Valjanovski. (Ed.), Privatization and Competition: A Market Prospectus. Institute of Economic Affairs, Harcourt Paperback

Zhang, Y. F., Parker, D., \& Kirkpatrick, K. (2008). Electricity sector reform in developing countries an Econometric assessment of the effects of privatization, competition and regulation. Journal of Regulatory Economics, 33(2). http://dx.doi.org/10.1007/s11149-007-9039-7

\section{Copyrights}

Copyright for this article is retained by the author(s), with first publication rights granted to the journal.

This is an open-access article distributed under the terms and conditions of the Creative Commons Attribution license (http://creativecommons.org/licenses/by/3.0/). 